\title{
Characterisation of germline mutations in the neurofibromatosis type 1 (NF1) gene
}

\author{
M Upadhyaya, J Maynard, M Osborn, S M Huson, M Ponder, B A J Ponder, \\ P S Harper
}

\begin{abstract}
Neurofibromatosis type 1 is one of the most common inherited disorders with an incidence of 1 in 3000. The search for NF1 mutations has been hampered by the overall size of the gene, the large number of exons, and the high mutation rate. To date, fewer than 90 mutations have been reported to the NF1 mutation analysis consortium and the details on 76 mutations have been published.

We have identified five new mutations using single strand conformation polymorphism (SSCP) and heteroduplex analysis (HA) and three intragenic deletions with the microsatellite markers. Of the five new mutations, two were in exon $27 a$, two in exon 45, and one in exon 49 and these include 4630delA, 4572delC, R7846X, T7828A, and one in the $3^{\prime}$ untranslated region ( $3^{\prime}$ UTR). The two nucleotide alterations in exon $27 a$ and the one in exon 45 are predicted to produce a truncated protein.
\end{abstract}

\section{(f Med Genet 1995;32:706-710)}

Neurofibromatosis type 1 (NF1) is one of the most common inherited disorders with a birth frequency of approximately 1 in 3000 . The disease is characterised by café au lait spots, neurofibromas, and Lisch nodules (hamartomas of the iris). NF1 has many complications which include complex neurocognitive difficulties, plexiform neurofibromas, and an increased risk of specific types of malignancy. ${ }^{1}$

The NF1 gene is more than $300 \mathrm{~kb}$ in size, consists of 59 exons, and has been mapped to $17 \mathrm{q} 11.2 .^{2-5}$ The NF1 transcript encodes a protein, neurofibromin, which is related to a number of GTPase activating proteins (GAP) and is involved in the negative control of ras mediated signal transduction. ${ }^{6}$ Neurofibromin also appears to be associated with cytoplasmic microtubules. This association between ras mediated signal transduction and the cytoskeleton suggests that neurofibromin may play multiple roles in the regulation of cell division.

The NF1 mutation rate, approximately $1 \times 10^{-4} /$ gamete/generation, ${ }^{8}$ is the highest described for any human disorder, and is some 100 fold higher than that usually found at a single locus, with the result that almost half of all cases of NF1 represent new mutations. This high mutation rate could either be because of the large size of the NF1 gene or the presence of highly mutable sequences within the gene.
The identification and characterisation of disease specific mutations in the NF1 gene should enable one to detect such mutational "hot spots" for mutations and to study correlation between the genotype and phenotype.

The search for NF1 mutations has been hampered by the overall size of the gene and the large number of exons. To date fewer than 90 mutations have been reported to the NF1 mutation analysis consortium, ${ }^{9}$ and details of only 76 of these mutations have been published. ${ }^{10}$ We have previously reported the identification of 14 mutations within the NF1 gene. ${ }^{11-14}$ We have since expanded our study to screen for NF1 gene mutations within exons 27a, 45, and 49 and here describe five new mutations identified by single strand conformation polymorphism (SSCP) analysis and heteroduplex analysis (HA). Three intragenic deletions have also been detected by analysing our families with intron specific microsatellite markers.

Materials and methods

We have studied a panel of 300 unrelated NF1 patients. The clinical details were available from the majority of the cases. Approximately 100 subjects represent sporadic cases, of which DNA from the parents was available from 11 . Several patients also have unusual clinical features associated with their disease.

DNA was extracted from peripheral blood leucocytes. DNA digestion and Southern based hybridisation and analysis was carried out as previously reported. ${ }^{12}$ DNA samples were amplified by PCR and the amplified products were then subjected to both SSCP analysis and HA.

Exons $27 \mathrm{a}$ and 45 were analysed by SSCP and the heteroduplex analysis was used for exon 49. Genomic DNA was amplified using $\left(\delta^{-33} \mathrm{P}\right)$ ATP end labelled primers. The radiolabelled PCR products were resolved on $5 \%$ non-denaturing acrylamide gel containing 5\% glycerol. PCR was routinely performed in a $6 \cdot 25 \mu$ reaction volume, containing $5 \mathrm{ng}$ genomic DNA, $20 \mathrm{pmol}$ of each primer, $200 \mu \mathrm{mol} / 1$ dNTPs, $50 \mathrm{mmol} / 1 \mathrm{KCl}, 10 \mathrm{mmol} / \mathrm{l}$ Tris $(\mathrm{pH}$ $8 \cdot 3$ ), $1 \cdot 0-1.9 \mathrm{mmol} / 1 \mathrm{MgCl}_{2}, 0.01 \%$ gelatin, and 1 unit of Taq polymerase (Amersham). The annealing temperatures used for the amplification of exons $27 \mathrm{a}, 45$, and 49 were $52^{\circ} \mathrm{C}$, $54^{\circ} \mathrm{C}$, and $53^{\circ} \mathrm{C}$ respectively, and the exon specific primer sequences used have been previously reported. ${ }^{9}$ DNA samples from 70 nonNF1 patients were also analysed as a control for each exon studied. 

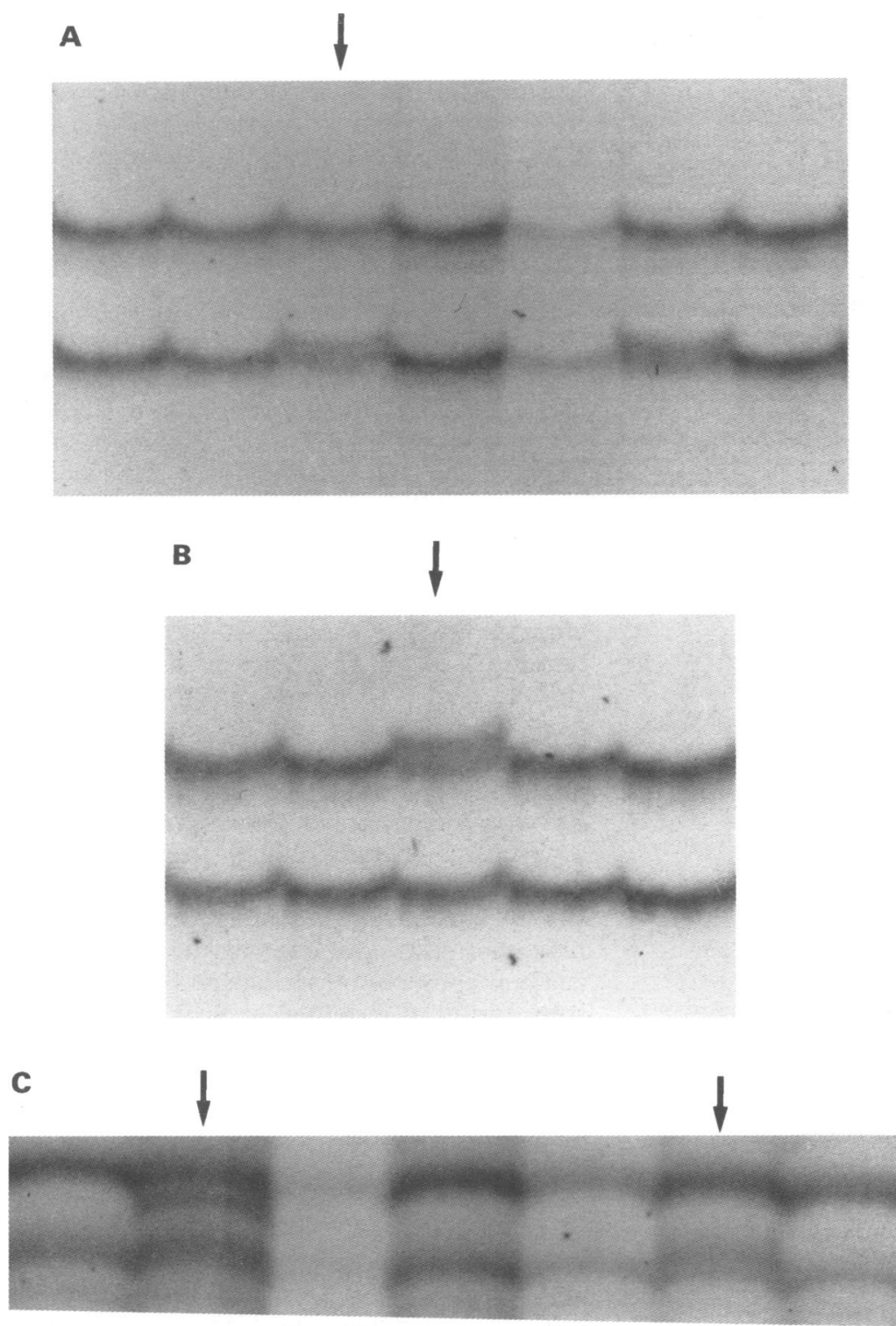

Figure 1 SSCP variant bands identified in NF1 patients; 5 ng genomic DNA was amplified using end labelled primers $\left(\delta^{-33} P\right)$ dATP. The radiolabelled PCR products were resolved on a 5\% non-denaturing polyacrylamide gel with 5\% glycerol. (A) Lane 3 contains a variant band observed in exon 45 of patient NF41. (B) Lane 3 contains a variant band in exon 45 in patient NF9. (C) Lanes 2 and 6 show variant bands in exon $27 a$ in patients NF173 and NF59.

For heteroduplex analysis, $150 \mathrm{ng}$ of amplified DNA $(2 \mu \mathrm{l})$ either from an NF1 patient and a control, or from two different NF1 patients, was added to $8 \mu \mathrm{l}$ water and $0.6 \mu \mathrm{l}$ EDTA $(0 \cdot 1 \mathrm{~mol} / \mathrm{l})$. The mixture was incubated at $94^{\circ} \mathrm{C}$ for three minutes and then slowly cooled from $42^{\circ} \mathrm{C}$ to $37^{\circ} \mathrm{C}$ over a period of one hour to allow for the formation of a heteroduplex. A $0.5 \mu \mathrm{l}$ quantity of loading buffer (Hoefer) was added to each sample. Samples were then electrophoresed on a $0.8 \times \mathrm{MDE}$ gel $(40 \times 30 \mathrm{~cm})$ in $0.5 \mathrm{TBE}$ buffer for 18 hours at $8 \mathrm{~W} .{ }^{15}$ The DNA in the gel was subsequently visualised by silver staining. ${ }^{16}$

Eleven sporadic NF1 cases for which DNA samples were also available from both normal parents were screened with two microsatellite markers located in the intronic regions of the NF1 gene (the AAAT polymorphism in intron 27 and the 1VS 38 GT 53.0 in intron 38). ${ }^{1718}$ Paternity in each family was assessed by screening with a panel of microsatellite markers located on several different chromosomes. To define the extent of the deletion identified, the DNA samples from the families with intragenic deletions were also studied for exon 5 and intron 41 polymorphisms. ${ }^{1920}$

Direct nucleotide sequencing was carried out on purified PCR product (Gene clean), using the dideoxy chain termination method (Sequenase version $2 \cdot 0 \mathrm{USB}$ ). Sequenase reactions were analysed on a $6 \%$ non-denaturing sequence gel, vacuum dried onto filter paper, and then exposed for 24 to 48 hours to $x$ ray film (Fuji) at room temperature.

\section{Results}

From a panel of 300 patients studied, five new mutations were identified and were fully characterised by direct sequencing. Of the five nucleotide alterations, four were identified by SSCP (fig 1). In addition, three de novo intragenic deletions were detected in three of the 11 sporadic cases. The details of each of these mutations are summarised in the table.

In patient NF59, the deletion of an adenine (A), at nucleotide 4630 in exon $27 \mathrm{a}$, generated a shift in the reading frame, resulting in the alteration of eight amino acids before the introduction of an inappropriate stop codon at nucleotide 4655 (fig 2 A,B). This mutation may result in the generation of a shortened nonfunctional protein of 1551 amino acids in com-

Details of the characterised mutations

\begin{tabular}{|c|c|c|c|c|c|c|c|c|c|}
\hline Exon & $\begin{array}{l}\text { No of patients or } \\
\text { families screened }\end{array}$ & $\begin{array}{l}\text { Analytical } \\
\text { method }\end{array}$ & $\begin{array}{l}\text { Patient } \\
\text { ID }\end{array}$ & Age & $\begin{array}{l}\text { Alteration at } \\
\text { nucleotide }\end{array}$ & $\begin{array}{l}\text { Amino acid } \\
\text { change }\end{array}$ & $\begin{array}{l}\text { Effect on } \\
\text { protein }\end{array}$ & $\begin{array}{l}\text { Type of } \\
N F 1^{*}\end{array}$ & $\begin{array}{l}\text { Clinical } \\
\text { phenotype }\end{array}$ \\
\hline $27 \mathrm{a}$ & 300 & SSCP & NF59 & & A deleted at 4630 & & $\begin{array}{l}8 \text { altered amino } \\
\text { acids before } \\
\text { termination at } \\
4655\end{array}$ & $\mathrm{~F}$ & $\begin{array}{l}\text { Cutaneous } \\
\text { involvement, no } \\
\text { complications }\end{array}$ \\
\hline $27 a$ & 300 & SSCP & NF173 & 29 & C deleted at 4572 & & $\begin{array}{l}27 \text { altered amino } \\
\text { acids before } \\
\text { termination at } \\
4655\end{array}$ & $S$ & $\begin{array}{l}\text { Cutaneous } \\
\text { involvement, plexiform } \\
\text { neurofibroma }\end{array}$ \\
\hline 45 & 200 & SSCP & NF9 & 80 & $\begin{array}{l}\mathrm{C} \rightarrow \mathrm{T} \\
7846\end{array}$ & Arg to stop & Truncated protein & $\mathrm{S}$ & $\begin{array}{l}\text { Cutaneous } \\
\text { involvement, plexiform } \\
\text { neurofibroma }\end{array}$ \\
\hline 45 & 200 & SSCP & NF41 & 53 & $\begin{array}{l}A \rightarrow G \\
7828\end{array}$ & Thr to Ala & & $S$ & $\begin{array}{l}\text { Cutaneous } \\
\text { involvement }\end{array}$ \\
\hline 49 & 284 & HA & NF130 & 40 & $\begin{array}{l}\mathrm{A} \rightarrow \mathrm{G} \\
11715\end{array}$ & 3' UTR & & $\mathrm{S}$ & $\begin{array}{l}\text { Mild cutaneous } \\
\text { involvement }\end{array}$ \\
\hline $27-38$ & 11 & Microsatellite & NF931 & 2 & $\begin{array}{l}\text { Deleted intron } 27 \text { to } \\
\text { intron } 41\end{array}$ & & Truncated protein & S & Noonan-like features \\
\hline 38 & 11 & Microsatellite & NF754 & 14 & $\begin{array}{l}\text { Deleted intron } 38 \text { to } \\
\text { intron } 41\end{array}$ & & Truncated protein & $\mathbf{S}$ & Learning problems \\
\hline 38 & 11 & Microsatellite & NF637 & 11 & Deleted intron 38 & & Truncated protein & $\mathbf{S}$ & Noonan-like features \\
\hline
\end{tabular}

$* \mathrm{~S}=$ sporadic, $\mathrm{F}=$ familial 


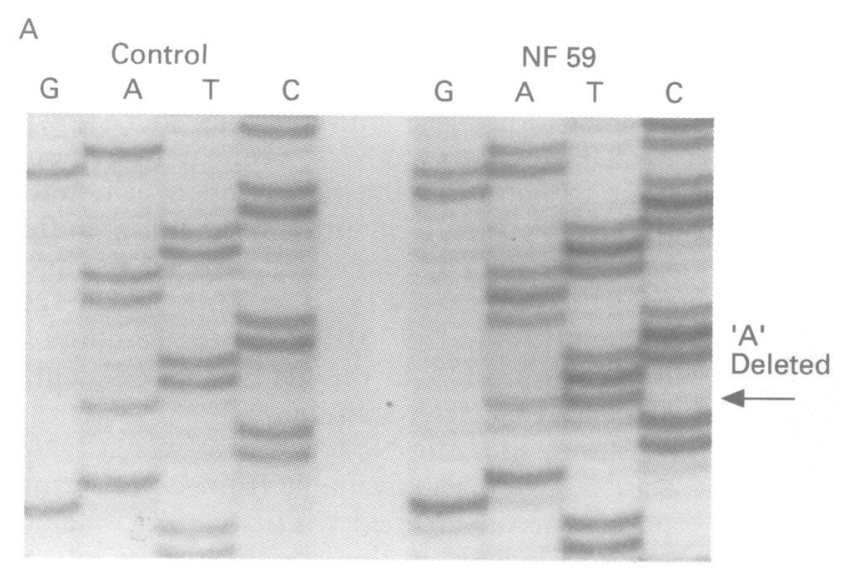

B

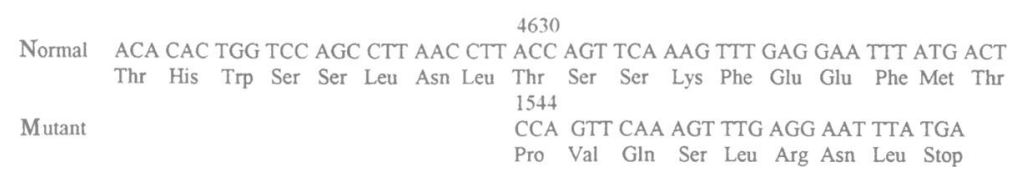

Figure 2 (A) Sequence analysis on patient NF59. The deletion of adenine at nucleotide 4630 in exon 27 a results in the alteration of the reading frame. (B) Adenine deletion results in eight altered amino acids different from the normal protein of the gene, which terminates prematurely at 4655.

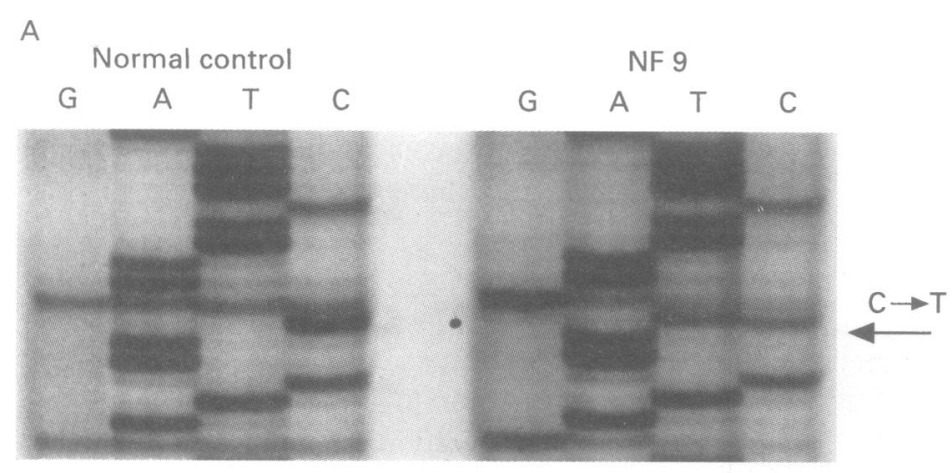

B

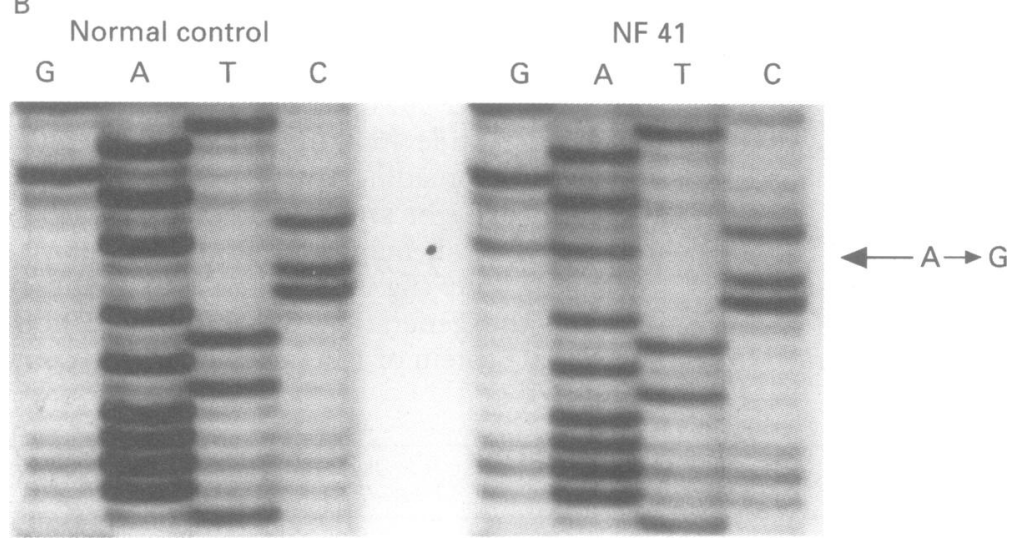

Figure 3 (A) DNA sequencing of patient NF9 in exon 45. A transition from cytosine to thymine at position 7846 results in a stop codon. (B) Sequence analysis of patient NF41 in exon 45. A transition from adenine to guanine at position 7828 results in the substitution of threonine to alanine.

parison to the 2818 amino acids of the normal protein. Unfortunately, although detailed clinical information is not available, this patient appears to have classical NF1.

In patient NF173, a deletion involving a cytosine $(\mathrm{C})$ at 4572 , in exon $27 \mathrm{a}$, also produces a change in the reading frame resulting in the alteration of 27 amino acids before the new stop codon at nucleotide 4655 . This nucleotide change also abolishes a restriction site for the enzyme BsaJI. This restriction site was present in DNA from her unaffected parents, indicating that the change in the patient is probably disease specific. This patient has typical cutaneous involvement and, in addition, macrocephaly, mild learning difficulties, and plexiform neurofibroma.

An alteration involving a base pair was identified within exon 45 in patient NF9; this involves a transition from $\mathrm{C} \rightarrow \mathrm{T}$ at position 7846 (fig 3A). This change occurs at a $\mathrm{CpG}$ dinucleotide and results in the conversion of an arginine to a stop at codon 2612 . This woman has typical major defining features with a large plexiform neurofibroma and she represents a new mutation.

In patient NF41, a transition involving a change from $A \rightarrow G$ at nucleotide position 7828 , which produces an amino acid substitution from threonine to alanine, was found (fig 3B). This alteration was not detected in any of the 70 normal controls or in 199 other NF1 patients. This mutational change also creates a new restriction site for the enzyme $A c i$ within a normally generated $269 \mathrm{bp}$ fragment, which as a result is cleaved into two fragments of $117 \mathrm{bp}$ and $152 \mathrm{bp}$, and the presence of this restriction site segregates with the disease. This is a non-conservative change and results in the substitution of a non-polar for a polar amino acid.

Only one new mutational change was identified by heteroduplex analysis on MDE gels. This was an $A \rightarrow G$ transition at nucleotide 11715 in exon 49 , within the $3^{\prime}$ UTR. This patient, NF130, has mild cutaneous involvement and no complications. She is the first case in her family. She has had three affected children from separate marriages and two of these children have NF1 and learning difficulties, but the samples from these were not available for analysis.

Eleven sporadic NF1 patients, where DNA was available from normal parents, were screened with two new microsatellite markers from within introns 27 and 38 . In three of these families, the affected subjects were found to be hemizygous at these CA repeats owing to the presence of interstitial deletions involving intron 27 to intron 38 of the NF1 gene in one case and only intron 38 in the other two NF1 patients (fig 4). In all three families, the origin of new mutation was in the maternal germlines. To define the extent of these three deletions, the families were further analysed by screening with the exon 5 polymorphism. ${ }^{19}$ Unfortunately all the affected subjects were homozygous for this polymorphism; however, with the intron 41 polymorphism, ${ }^{20}$ the NF1 patient from two families had not inherited the maternal allele. The precise extent of these three deletions remains to be determined.

\section{Discussion}

The detection of disease specific mutation in sporadic cases of neurofibromatosis type 1 (NF1) is crucial for the successful genetic coun- 
A

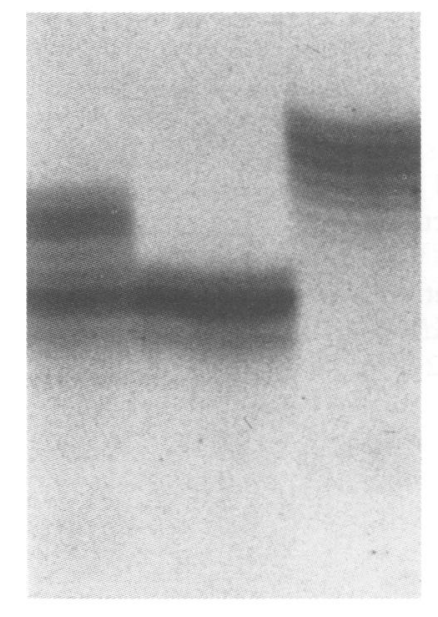

B

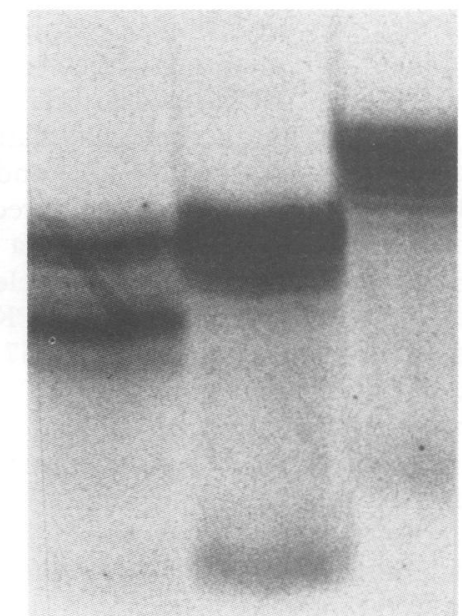

c

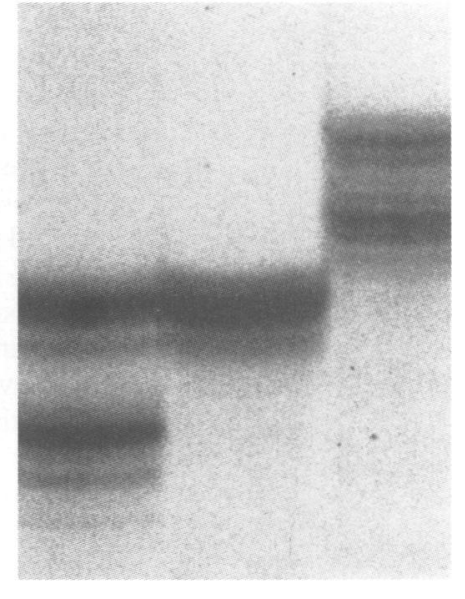

Figure 4 Hemizygosity for a CA repeat IVS 38 GT 53.0 (intron 38) in three new mutation NF1 families. Panel $A$ shows lanes 1-3 containing DNA from father, affected child, and mother. The child has not inherited a maternal allele. $A$ similar patterm of non-maternal inheritance is observed in panels $B$ and $C$.

selling and prenatal diagnosis of such families. The limited number of mutations so far reported in the NF1 gene include both large and small DNA rearrangements as well as the whole spectrum of point mutations, including splice site, missense, and nonsense mutations. ${ }^{10}$

We have identified five new mutations and three intragenic deletions (table). The two nucleotide alterations identified in exon $27 \mathrm{a}$, as well as the one in exon 45 , are all predicted to produce a truncated protein and are, therefore, expected to be disease causing mutations. The majority of NF1 mutations described to date have involved nucleotide alterations that would be predicted to result in a loss of neurofibromin production from the mutant allele. The protein truncation test (PTT) has recently been used to detect frameshift and nonsense mutations in both the Duchenne muscular dystrophy (dystrophin) and the adenomatous polyposis coli (APC) genes. ${ }^{2122}$ Approximately $70 \%$ of previously identified mutations in the NF1 gene were also readily identifiable using the PTT. ${ }^{2324}$ Thus the PTT appears to be a very promising assay system for mutational analysis of the NF1 gene and clearly has the potential to detect the majority of NF1 mutations.

An alteration involving $A \rightarrow G$ at position 7828 in patient NF41 was not seen in 70 control samples. Further investigations are required to identify and define the role of such missense mutations in the aberrant function of neurofibromin. Functional studies will be required to understand the underlying mechanism by which this threonine to alanine substitution causes disease.

An identical mutation, C5839T, at $\mathrm{CpG}$ dinucleotide has been described in exon 31 in six unrelated NF1 subjects who exhibit a spectrum of phenotypes. ${ }^{25-29}$ We have also previously reported identical changes in exon 17 in two unrelated NF1 patients whose phenotypic features were different. ${ }^{14}$ The clinical phenotype of NF1 is extremely variable, even within families, making a straightforward relationship between genotype and phenotype unlikely.
Easton et $a l^{\beta 0}$ have presented evidence based on analysis of the variation of clinical features within family members for the role of modifying genes in determining the NF1 phenotype. The analysis, however, could not exclude that the NF1 genotype would be important for at least some disease features. The limited number of mutations reported to date has not allowed detailed analysis of this. The patients reported here will facilitate genotype/phenotype correlation but they provide no immediate obvious insights into this question.

To date, a total of 16 nucleotide substitutions have been reported in the NF1 gene. ${ }^{1025-2931}$ Indeed, eight of the 16 nucleotide substitutions so far reported in over 600 patients screened involve a $\mathrm{C} \rightarrow \mathrm{T}$ change at a $\mathrm{CpG}$ dinucleotide. The change in patient NF9 in the present study also involves a $\mathrm{CpG}$ dinucleotide. There is now clear evidence that the presence of $\mathrm{CpG}$ dinucleotides are associated with a high mutation rate, as it has been shown that alterations at these dinucleotides account for at least $35 \%$ of all point mutations causing genetic disorders. ${ }^{32}$

In patient NF130, the $A \rightarrow G$ change at nucleotide position 11715 is within the $3^{\prime}$ UTR distal to exon 49 and is the only change so far reported in this region. She has three affected children from separate marriages and two of these children have NF1 and learning difficulties. It has been reported that the $3^{\prime}$ UTR of the human NF1 gene is highly conserved in the mouse, ${ }^{33}$ and therefore mutations within this region may be important for mRNA stability or translational efficiency.

Mutations have been found to occur nonrandomly with respect to the surrounding DNA sequence in human genes. ${ }^{3234}$ Certain sequences in the human genome are associated with the preferential formation of insertions and deletions. These sequence patterns include direct repeats, palindromes, quasi-palindromes, and runs of identical bases. This is consistent with a mutational mechanism based on the slipped mispairing model which suggests that misalignment can occur between such dir- 
ect repeats during replication. The nucleotide environment for some of the NF1 gene deletions and insertions detected in the previous studies has also provided similar examples of flanking sequences containing direct repeats, palindromes, and quasi-palindromes. ${ }^{13356}$ However, on examining the sequences flanking both the cytosine deletion in NF173, and the adenine deletion in NF59, no such direct or inverted repeats were observed (data not shown). However, a perfect copy of a deletion "hot spot" consensus sequence TGPPKMP was found in close proximity to del $4572 \mathrm{C}^{32}$ (M Krawczak, personal communication).

The three NF1 patients who showed hemizygosity with several microsatellite markers, owing to the presence of an intragenic deletion, all have learning problems. Interestingly, two of these deletion cases have NF-Noonan-like features which include hypertelorism and downward slanting palpebral fissures, posteriorly rotated ears, a short neck, and low posterior hairline. Hemizygosity with these microsatellite markers has previously been reported in several classical NF1 patients. ${ }^{37}$ Unequal exchange between homologous chromosomes during meiosis may account for the high rate of intragenic deletions observed in this gene. In contrast to previous reports, where $95 \%$ of all new mutations appear to be of paternal origin, ${ }^{38} 39$ all three deletion cases in our study were of maternal origin.

The introduction of more sensitive analytical methods, such as the protein truncation test and direct RT-PCR of total cellular RNA, as well as a more comprehensive analysis of each of the exons of the gene, should help to identify the majority of NF1 mutations. The possibility that there is a clustering of mutations within the region of the gene that has not yet been analysed cannot be ruled out. As a growing number of causative germline mutations are identified, the overall mutational spectrum will become clearer. This will be useful for elucidating the normal gene function and would also provide us with valuable insights into the intricacies of underlying mutational mechanisms.

We would like to thank Drs Angus Clarke, Peter Lunt, and Angela Barnicoat, and all the clinicians and the families who have provided samples for this study. We are extremely gratefu to Dr N Thomas for useful comments. This work was supported by Action Research and Sir Stewart Halley Trust.

1 Huson SM, Compton DAS, Clark P, Harper PS. A genetic study of von Recklinghausen neurofibromatosis in south east Wales. I Prevalence, fitness, mutation rate, and effect of paternal transmission on severity. $\mathcal{F}$ Med Genet 1989; 26:704-11.

2 Barker D, Wright E, Nguyen K, et al. Gene for von Recklinghausen neurofibromatosis is in the pericentric region of chromosome 17. Science 1987;236:1100-2.

3 Seizinger BR, Rouleau GA, Ozelius Z, et al. Genetic linkage of von Recklinghausen neurofibromatosis to the nerve growth factor receptor gene. Cell 1987;49:589-94.

4 Wallace MR, Marchuk DA, Andersen LB, et al. Type I neurofibromatosis gene: identification of a large transcrip disrupted in three NF1 patients. Science 1990;249:182-6.

5 Viskochil DH, Buchberg AM, Xu G, et al. Deletion and a translocation interrupt a cloned gene at neurofibromatosis translocation interrupt a cloned gene

6 Xu G, O'Connell P, Viskochil D, et al. The neurofibromatosis type 1 gene encodes a protein related to GAP. Cell 1990;62:599-608.

7 Collins FS, Gutmann DH, Mitchell AL, et al. Molecular genetics of neurofibromatosis type 1. $\mathcal{F}$ Cell Biochem Suppl .

8 Huson SM, Hughes RAC. The neurofibromatoses: a clinical and pat 1994 .

9 Korf B NNFF international NF1 genetic analysis consortium newsletter. 1994;2:1-11.

10 Upadhyaya $M$, Shaw DJ, Harper PS. Molecular basis of neurofibromatosis type 1 (NF1): mutation analysis and polymorphisms in the NF1 gene. Hum Mutat 1994;4: 83-101.

11 Upadhyaya M, Cherryson A, Broadhead W, et al. A $90 \mathrm{~kb}$ DNA deletion associated with neurofibromatosis type 1 . f Med Genet 1990;27:738-41.

12 Upadhyaya $M$, Shen $M$, Cherryson $A$, et al. Analysis of mutations at the neurofibromatosis 1 (NF1) locus. Hum Mol Genet 1992;1:735-40.

13 Shen $M$, Upadhyaya $M$. A de novo nonsense mutation in exon 28 of the neurofibromatosis type 1 (NF1) gene. Hum Genet 1993;92:410-12.

14 Shen $M$, Harper PS, Upadhyaya M. Neurofibromatosis type 1 (NF1): the search for mutations by PCR heteroduplex analysis on hydrolink gels. Hum Mol Genet 1993;2:1861-4. Prior TW, Papp AC, Snyder PJ, et al. Identification of two point mutations and a one base deletion in exon 19 of the
dystrophin gene by heteroduplex formation. Hum Mol dystrophin gene by het
Genet 1993;2:311-13.

16 Highsmith WE Jr. Carrier screening for cystic fibrosis. Clin Chem 1993;39:706-7.

17 Xu G, Nelson L, O'Connell P, White R. An Alu polymorphism intragenic to the neurofibromatosis type 1 gene (NF1). Nucleic Acids Res 1991;19:3764.

18 Lazaro C, Gaona A, Xu G, Weiss R, Estivill X. A highly informative CA/GT repeat polymorphism in intron 38 of human neurofibromatosis type 1 (NF1) gene. Hum Genet 1994;92:429-30.

19 Hoffmeyer S, Assum G. An Rsal polymorphism in the neurofibromatosis (NF1) gene. Hum Genet 1994;93:4812.

20 Shen $M H$, Upadhyaya $M$. Two single base polymorphisms in introns 41 and 16 of the NF1 gene. Am $\mathcal{F}$ Med Genet 1995;60:147-9.

21 Roest PAM, Roberts RG, Sugino S, van Ommen GJB, den Dunnen JT. Protein truncation test (PTT) for rapid detection of translation-terminating mutations. Hum Mol Genet 1993;2:1719-21.

22 Powell SM, Petersen GM, Krush AJ, et al. Molecular diagnosis of familial adenomatous polyposis. $N$ Engl $f$ Med 1993;329:1982-7.

23 Heim RA, Silverman LM, Farber RA, Kam-Morgan LNW, Luce MC. Screening for truncated NF1 proteins. Nature Genet 1994;8:218-19.

24 Cawthon R, Breidenbach HH. Identification of NF1 mutations by a protein truncation assay. Am $\mathcal{F}$ Hum Genet Suppl 1994;55:A1256.

25 Cawthon RM, Weiss R, Xu G, et al. A major segment of neurofibromatosis type 1 gene: cDNA sequence, genomic structure and point mutations. Cell 1990;62:193-201.

26 Estivill X, Lazaro C, Casals T, Ravella A. Recurrence of a nonsense mutation in the NF1 gene causing neurononsense mutation in the NF1 gene causing
fibromatosis type 1 . Hum Genet 1991;88:185-8.

27 Ainsworth PJ, Rodenhiser DI, Costa MT. Identification and characterisation of sporadic and inherited mutations in exon 31 of the neurofibromatosis (NF1) gene. Hum Genet 1993;91:151-6.

28 Horiuchi $T$, Hatta $N$, Matsumoto $M$, et al. Nonsense mutations at Arg-1947 in two cases of familial neurofibromatosis type 1 in Japanese. Hum Genet 1994;93:81-3.

29 Valero MC, Velasco E, Moreno F, Hernnandez-Chico C. Characterisation of four mutations in the neurofibromatosis type 1 gene by denaturing gradient gel electrophoresis (DGGE). Hum Mol Genet 1994;3:639-41.

30 Easton DF, Ponder MA, Huson SM, Ponder BAJ. An analysis of variation in expression of neurofibromatosis type 1 (NF1): evidence for modifying genes. Am $\mathcal{f} \mathrm{Hum}$ Genet 1993;53:305-13.

31 Purandare S, Lanyon WG, Connor JM. Characterisation of inherited and sporadic mutations in neurofibromatosis type 1. Hum Mol Genet 1994;3:1109-15.

32 Cooper DN, Krawczak M. Human gene mutation. Oxford: BIOS Scientific Publishers, 1993.

33 Bernards A, Snijders AJ, Hannigan GE, Murphy AE, Gusella JF. Mouse neurofibromatosis type $1 \mathrm{cDNA}$ sequence reveals high degree of conservation of both coding and non-coding mRNA segments. Hum Mol Genet 1993;2:

34 Cooper DN, Krawczak M. Mechanism of insertional mutagenesis in human genes causing genetic disease. Hum Genet 1991;87:409-15.

35 Stark $M$, Assum $G$, Krone W. A small deletion and an adjacent base exchange in a potential stem-loop region of the neurofibromatosis type 1 gene. Hum Genet 1991;87: 685-7.

36 Hatta N, Horiuchi T, Fujita S. Analysis of NF gene mutations in neurofibromatosis type 1 patients in Japan. Biochem Biophys Res Commun 1994;199:207-12.

37 Lazaro C, Gaona A, Ravella A, et al. Novel alleles, hemizygosity and deletions at an Alu-repeat within the neurofibromatosis type 1 (NF1) gene. Hum Mol Genet 1993;2: 725-30.

38 Jadayel D, Fain P, Upadhyaya M, et al. Paternal origin of new mutations in von Recklinghausen neurofibromatosis. Nature 1990;343:558-9.

39 Stephens K, Kayes L, Riccardi VM, Rising M, Sybert VP, Pagon RA. Preferential mutation of the neurofibromatosis Pagon RA. Preferential mutation of the neurofibromatosis type 1 gene in paternall
Genet $1992 ; 88: 279-82$. 